\title{
Useful Trends of German Current Value Accounting?
}

\author{
Andreas Haaker ${ }^{1}$ and Patrick Velte ${ }^{2^{*}}$ \\ ${ }^{1} D G R V$ - the German Cooperative and Raiffeisen Confederation Association, Berlin, Germany \\ ${ }^{2}$ Professor for Accounting \& Auditing, Leuphana University Lueneburg, Germany \\ *Corresponding author: Patrick Velte, Professor for Accounting \& Auditing, Leuphana University Lueneburg, Germany, Tel: +04131 677-2117; E-mail: \\ patrick.velte@leuphana.de
}

Rec Date: Oct 25, 2014; Acc Date: Oct 29, 2014; Pub Date: Nov 05, 2014

Copyright: (C) 2014 Haaker A, et al. This is an open-access article distributed under the terms of the Creative Commons Attribution License, which permits unrestricted use, distribution, and reproduction in any medium, provided the original author and source are credited.

\begin{abstract}
The rational management of the current value accounting according to the fair value concept is one of the major problems. The history of current value accounting in Germany has not been researched very well yet. Although, some aspects of history would certainly provide new insight into the recent developments that led to a strengthening of the fair value measurement. The "modern" fair value concept increasingly applied in the International Financial Reporting Standards (IFRS) was already known and used in Germany in the $19^{\text {th }}$ century. Based on the experience of the founder crisis the fair value concept was abolished in 1884 while at the same time the acquisition cost principle was introduced. It was precisely during the recent financial crisis that fair value accounting was (re-)introduced into the German accounting law, although it is likely that this concept negatively affected the crisis. In this paper the history of current value accounting in Germany will be discussed against the background of these contradictions. We also focus the accounting modernization in Germany during the financial crisis in 2009 , as well as a comparative tax-related evaluation of the fair-value concept.
\end{abstract}

Keywords: Financial accounting; Founder crisis; Fair value; Realization principle; German Accounting Law Modernisation Act

\section{Introduction}

The history of current value accounting for assets within German commercial law and tax law accounting beginning with the Prussian Civil Code in 1794 until the German Accounting Law Modernisation Act (BilMoG) in 2009 was rather changeful [1,2]. International literature did not yet provide a complete picture of these developments. Hence, substantial contradictions in the history were not recognized. This is regrettable since we finally investigate historical developments because we try to learn more about current and urgent accounting problems.

It is widely regarded that current value accounting (so-called fair value accounting) has been "fuelling" the recent financial crisis. Nevertheless, it was during this very financial crisis that it was (re-)introduced to banks in Germany in 2009. By contrast, current value accounting was abolished by the German legislature in 1884 on account of the founder crisis. The reasons given by the German legislature 128 years ago, which are entirely apposite to the current crisis, should have been taken into consideration before modernization of the German Commercial Code was effected. We will concentrate on a comparative evaluation of fair value measurement since commercial accounting and tax accounting are closely linked in Germany.

The negative experience of the founder crisis after 1870/71 lead to a predomination of conservative accounting analysis; prohibiting the disclosure of not realized profits according to the realization principle and requiring a strict orientation on the costs of purchase as upper value limit. The under-valuation of assets through the set up of provisions as potential liability-reserves provides for a major part of the financial creditor protection within the German accounting system. Even in case of asset appreciation the distribution of profits is retained until the market transaction has been realized (realization principle). Since the introduction of the BilMoG in 2009, credit and financial service institutes are obliged to evaluate financial instruments held for trading at current value (so called fair value) according to $\$$ 340 e para. 3,4 German Commercial Code (HGB) and $₫ 6$ para. 1 no. 2b German Income Tax Code (EStG). However, this leads to clear disrespect of the acquisition cost principle since without a market transaction not-realized valuation profits are being collected and the realization principle is not adhered to. The "modern" and internationally oriented view of the German legislator demanding for more useful information in financial accounting at the expense of creditor protection requires critical analysis. The respective analysis should be based on the development of current value accounting in commercial and tax law. Eventually, the corresponding legislative process coincided with the latest financial crisis, where current value accounting proved to be as difficult as during the founder crisis, which in turn initiated the rejection of the current valuation in 1884. The present paper addresses and analyses the different stages of the historical development of current value accounting in the German accounting system. As a result, the rescission of the violation of the realization and acquisition cost principle introduced (again) by the BilMoG is recommended. This is consistent with the opinion of the former legislator in 1884, influencing the German accounting law from that time on.

First, a legal historic analysis of current value accounting in terms of commercial and tax law as well as a balance sheet theoretical classification is provided. Then, it is discussed whether the special regulation with regard to parity current value accounting, introduced by the latest balance sheet reform, is consistent with commercial and tax law accounting purposes. The results of the analysis indicate that in spite of a deduction for risk on the fair value and the compulsory building up of special reserves, the creditor protection of credit and 
financial service institutions is thwarted. In addition, the principle of fiscal capacity and the principle of taxation equity are violated. The interdisciplinary research approach combines the historical and balance sheet theoretical analysis, both being indispensable for an adequate assessment of the development of current value accounting.

\section{Legal Historic Development and Theoretical Foundation of Current Value Accounting}

\section{Specification of commercial evaluation standards with regard to parity current value accounting between 1794-1870}

Within the legal historical timeline, it can be observed that commercial and fiscal valuation of acquired assets of the fixed assets and current assets provide for acquisition costs as upper value limit and that this has been exceeded within the framework of parity current value accounting. Valuation principles for the preparation and publication of annual financial statements were determined for the first time in 1794 in the Prussian Civil Code (ALR). Primarily, the ALR was based on the French "Ordonnance de Commerce" of 1673 and the largely unchanged published "Code de Commerce" of 1807 [3]. A member of the commission of the Ordonnance, Savary, suggested in his commentary "Le Parfait Négociant" (The perfect trader) the valuation of assets to acquisition costs, e.g. lower purchasing costs in case the value of acquisition costs fall below by more than $5 \%$ (lower of cost or market principle). The orientation on acquisition and lower of cost or market principle can be qualified as common business conduct of decent traders in the single German states at that time. Since explicit valuation principles were missing in the Ordonnance, the ALR adopted the interpretations of Savary in $\$ 644 \mathrm{f}$ for current assets, complemented in $\$ 645$ ALR by the amortization of investment goods that are depreciated as a result of a longer period of storage or usage. However, the valuation principles of the ALR for all trading companies in question were not legally binding. The regulations of the companies agreement were allowed to arrange for an appreciation with regard to acquisition costs and hence a time valuation on parity terms. So far the legislator did not pay special attention to the creditor protection by maintenance of capital based on the valuation according to stock corporation law concession and the unlimited liability in case of single and business partnership. Similar applied to the Prussian law on stock corporations of 1843 and the stock regulative of 1856 [4].

Standardized valuation principles were implemented first in the ADHGB) of 1861 for the states of the German Confederation. In contrast to the dispositive acquisition cost principle of the ALR, article 31. para. 1 of the ADHGB 1861 provided for the attributed value as standard valuation for all assets and receivables. However, the attributed value has not been defined in more detail on purpose and was taken as an interim solution, e.g. least common denominator of the proceedings of the commission. The prevailing opinion in literature interpreted the attributed value in terms of current value, e.g. unit sell price, leading to predominate exceeding of acquisition costs even without company-law regulations according to the ADHGB 1861. At a later date, this view has been mentioned in the organic accounting theory by Fritz Schmidt and was justified by the selfinformation duty of the trader. In spite of an orientation on dividend interests in financial profits, the payment assessment function of the balance sheet was not highlighted. Non-observance of the realization principle enabled distribution of not realized profits by appreciation in value of assets, exceeding the acquisition costs; causing serious problem during the founder crisis.
The economic expediency of a parity current value accounting was a subject of fierce debate in the corresponding literature after the stock law act of 1870 and the foundation of the German empire. While the governmental necessity for concession was repealed for stock corporations, the stock laws act in art. 239a Para. 1 ADHGB 1870 provided for a valuation at market value on closing date only for listed securities. Since the majority of the newly found stock corporations were railway companies with a high number of asset investments, Keyszner [5] and Loewenfeld [6] approved the acquisition cost principle according to the subjective value theory for the valuation of fixed assets.

The separation of valuation standards can be explained by the understanding that valuation should be influenced by the assigned purpose of the commodity (long term or short term disposition in the company). With regard to fixed assets, the appreciation of the trader is more in focus as a result of the purchase. However, with regard to current assets, the expectations of potential consumers would influence the valuation, thus leading to a (parity) current value accounting. This separation of valuation standards is consistent with the continuing static accounting theory of Simon [7]. According to this basic theory, the valuation of assets is effected to their individual value, e.g. fixed assets to (continuing) acquisition cost and currents assets to realization price. Also, jurisdiction and corresponding literature are in line with this understanding. In contrast, the organic accounting theory of Fritz Schmidt [8] arranged for a valuation of the total balance sheet assets (including fixed assets) to current acquisition price (current value) in order to disclosure the real value of asset.

Within the framework of the dynamic accounting theory, the introduction of an upper value limit in terms of (continuing) acquisition costs for fixed and current assets were focused. According to this view, the strict highlighting of the acquisition cost principle is common trading law for all assets, demanding for current value accounting not to exceed the upper value limit. Possible shortage of liquidity of the trader as a result of too high profit withdrawal can only be avoided - according to Fischer [9] - through strict orientation on the realization principle, preventing the reporting of not-realized profits by means of acquisition costs as upper value limit. This typical view is still being argued against the modern characteristic of current value accounting (fair value accounting). Schmalenbach [10] as a prominent representative of the dynamic accounting theory did not argue in favour of this restrictive approach at first. In fact, current assets held for reasons of speculation ought to be evaluated at a higher current value in case of reliable assessment. Yet, in later years, Schmalenbach emphasized due to precaution considerations a general application of the lower of cost or market concept for all assets. The lower of cost or market concept corresponds to a cautious imparity current value accounting; only determining changes in value in case the value was falling below the acquisition cost limit.

\section{Imparity current value accounting in commercial law from 1884-2004 and fiscal deviations from 1808-1934}

With good cause, the stock law act of 1884 finally implemented the acquisition cost principle as upper value limit in article $185 \mathrm{a}$ and $239 \mathrm{~b}$ ADHGB of 1884 for fixed and current assets. As a reaction to the founder crisis, the legislator prohibited the disclosure of a higher current value. As a result, values exceeding the costs of acquisition could be realised and distributed to the shareholders first when sold on the market (realization concept). The imparity current value accounting ought to be an instrument of financial precautions in terms 
of a balance sheet supported maintenance of capital for limited partnerships on shares and for stock corporations. For other legal forms of a company such as the comparable limited liability company, the acquisition cost principle was not to be applied; however, the commercial practice was different in reality. The categorization of the valuation principles according to the legal form of the company was justified by the diverse purposes of the balance sheet. The distribution balance sheet is used for the distribution to shareholders in stock corporations. In contrast and according to the Prussian Upper Administrative Court [11] the balance sheet of a sole-proprietor is representing a real assets balance sheet independent from any interest regarding the distribution. However, the empire court [12] was in favor of an expansion of the legal distribution ban to other legal forms of a company and in addition supported a general upper value limit of assets to acquisition costs, in line with Savary and the ALR.

After the introduction of the realization principle in 1884 it was interpreted by Schmalenbach as of one of the most important principles of orderly accounting whose violation in the founder years after 1871 always felt like cheating to the decent traders. The draft law referred to a dark picture of a tremendous number of new stock corporations and their inevitable crashing that lead to a damage of the public wealth. The stock exchange crash was intensified by a higher current valuation of virtual valuation since the premature profit disclosure raised the volume of the payouts and reduced the operating liability amount: where profit orientation and credulousness meet a balance sheet a preparation according to the fiercest rules is necessary in order to prevent a determination of imaginary success. Here, clear similarities can be found with regard to the controversial discussions after the founder crisis and the BilMoG, whose legislative procedure took place within the framework of the financial crisis 2008-09. The aforementioned arguments of the former legislator against the current valuation and in favor of the highlighting of the acquisition cost and realization principle could have been applied easily also for the GALMA. Though, the legislator consciously accepted the violation of the realization principle in contrast to the previous accounting law and finally did not follow the conclusion of the former legislator according the stock law act of 1884 . This will be described in detail later. Instead, since the introduction of the BilMoG, credit and financial service institutions are obliged to valuate financial instruments held for trading in parity to the fair value according to $\$ 340$ e Para. 3, 4 HGB (German Commercial Code) and $\$ 6$ Para. 1 no. $2 b$ EStG (German Tax Law).

The concretion of income tax accounting and the corresponding valuation principles for economic goods developed far more slowly. Tax on earnings as a surplus revenue calculation independent from the commercial law accounting regulation of the trader, was introduced first in the Prussian provinces Ostpreußen and Litauen in 1808 and then later in 1812 for entire Prussian. Similar holds true for the implementation of income tax in Wuerttemberg (1820), Sachsen (1834), Nassau (1848), Bavaria (1848), Bremen (1862) and Hamburg (1866), at first not providing for a business property comparison (balance sheet comparison). This changed first with the introduction of the authoritative principle relating to commercial law for the tax balance sheet in Sachsen and Bremen in 1874 as well as in Prussia in 1891, allowing for an adoption of the valuation principles of the Generally German Commercial Code (ADHGB) for the determination of taxable income.

During the discussion on Prussian income tax act of $24^{\text {th }}$ of June 1891, committee member Goldschmidt argued for the implementation of the acquisition cost principle in terms of commercial law according to article 185a ADHGB as the income tax upper valuation limit was without success. Yet, the majority of the commission members were convinced that the single trader could not be forced to prepare his balance sheet in accordance with the regulations for stock corporations. The danger of a potential overvaluation of commercial goods was countered by the assumption that the decent trader would balance between the principle of prudence in terms of commercial law and a full disclosure of profits. In addition, a proposed facultative codification of the upper value limit of art. 185a ADHGB into the income tax act was not realized, in fact the minister of finance Miquel assured an accommodating dealing with taxpayer.

Hence, after the stock law act in 1884, a discrete fiscal interpretation of valuation according to fair value in line with article 31 ADHGB was codified. Amongst others, the Saxon Higher Administrative Court [13] provided for parity current valuation for all legal forms of a company. The corresponding violation of the acquisition cost principle can be interpreted as a full taxation of profits. Moreover and in contrast to the static accounting theory, the Saxon Higher Administrative Court did not want to limit the higher current value to certain goods of the current assets. Correspondingly, the Prussian Upper Administrative Court [14] put the fair value - mentioned in art. 31 ADHGB - on a level with the common value. This valuation standard was defined already in $\$ 112$ ALR as the benefit of the goods for the owner. Whereas the Prussian High Tribunal [15] determined the capitalized value, the Prussian Upper Administrative Court argued for the market price. The common value was determined for the first time according to tax law by the growth rate tax-implementation rule in 1911 as sales value or commercial value which is realized in the common trading according to the nature of the goods without taking into account any other rare or personnel condition.

Thereby, even at the beginning of the $20^{\text {th }}$ century the continuous valuation of assets at a (higher) current value in terms of the common value was highlighted from a fiscal perspective. However, Mirre [16] disagreed with the single valuation consideration of the Prussian Upper Administrative Court, referring to the fact that the company value cannot explain the sum of the single assets valuation and debts entirely but that multifaceted economies of scope exist. The value reflecting the economic content of the assets for the entire company (overall valuation) should be expressed by the partial value. This fiscal dominant value standard was confirmed for the first time by the Empire Fiscal Court and finally in 1934 added as replacement for the common value in $\$ 6$ Abs. 1 EStG. Until that time, the taxpayer had to refute the partial valuation assumptions of the Empire Fiscal Court and later Federal Fiscal Court (BFH), in case he wanted to devalue the goods below the costs of replacement.

For the first time, the decision of the Saxon Upper Administrative Court allowed for the application of commercial acquisition cost principle as upper value limit regarding the determination of taxable income. On the federal state level, it was defined in the Bavarian income tax act of 1910. The executive order stipulated that the valuation of assets permanently used for the company's business as well as other items were done at the real orat least corrected acquisition price less an appropriate depreciation.

In the German Empire, this principle was codified in the income tax act of 1920 in $\$ 32$ Para. 2, $\$ 33$ Para. 1 EStG. With regard to traders, not keeping the books according to commercial law, it was still possible to valuate goods to the common value and thus charging tax on not realized profits. However, an option existed with regard to the 
application of lower acquisition price. According to $₫ 33$ a EStG of the income tax act of 1921 valuation variance between common value and acquisition costs did not have to be disclosed (lower common value), thus avoiding a taxation of not realized profits. On the contrary, the income tax act of 1925 allowed for the alternative valuation between (higher) common value and acquisition cost according to $\$ 19$ Para. 1, 2 and $\$ 20$ Para. 1 EStG. Only with the income tax act of 1934 the acquisition costs were codified explicitly in $₫ 6$ ESTG as preferential value standard and highest tax value for acquired goods of fixed assets and current assets.

In terms of commercial law, an institutional continuity within accounting law followed already after the 1884 stock law act. The valuation principles for limited partnerships on shares as well as public corporations did not change in $\$ 261 \mathrm{HGB}$ (of 1897) and $₫ 40$ para. 2 HGB (of 1900) nor in the reform acts of 1937 and 1965. Yet, it was only with the Accounting Directives Act (BiRiLiG) of 1985 that the lower of cost or market concept according to $₫ 253$ HGB as well as the realization principle pursuant to $\$ 252$ para. 1 no. 4 HGB was clearly codified for all traders and assets. The former separation into the fair value for all traders according to $\$ 40$ para. 2 and 3 HGB and into the special regulations of other legal entity rules were finally abandoned. Hence, the law adapted to the traders practice that never complied with the valuation principles of current value accounting. The national legislator abandoned the right of the European Member States regarding the revaluation of assets above the acquisition costs accordingly.

Despite the European accounting harmonization, a privat standard setter was founded in London. Later, the International Accounting Standards Committee that was founded in 1973 (IASC, today's successor: International Accounting Standards Board - IASB), became more important with the increase in internationalization of capital markets. Therefore, the focus was on capital market oriented companies in the European Union that were obliged to prepare their consolidated financial statements according to International Financial Reporting Standards (IFRS) since 2005. Given the corresponding orientation on the interests of providers of risk capital, the IASB performed a continuing reversal of trend in favour of current valuation. This change is being viewed very critically with regard to commercial and tax accounting purposes and financial market stability. Moreover, the pro-cyclical and crisis intensifying effect of current valuation is seen as a substantial risk.

Yet, several members in favor of the European accounting harmonization prefer the IFRS as harmonization model, although the IASB approved the IFRS for Small and Medium-Sized Entities (IFRS for SMEs) in 2009. Meanwhile the German Accounting Law Reformation Act (BilReG) of 2004 clearly indicated that the financial statement in terms of commercial law provides the basis for the dividend distribution and taxation and not the annual financial statement according to IFRS. As defined by the decoupling approach of information, companies were obliged according to $\$ 285$ no. 18 HGB to disclose the higher current value of derivative financial instruments only in the notes but not in the financial statement. However, publicly traded credit institutes were exposed to an increase in expectations of investors to fulfil their distribution expectations in terms of not realized current value profits of the IFRS consolidated financial statement. In order to consider these expectations to be fulfilled, bigger credit institutes tend to evaluate their assets to current value even in the distribution relevant individual financial statement thus violating the law. For the first time, the Deutsche Bank was trifling with the law and used the fair value method of valuation for its financial instruments held for trading. Other institutions adapted to this example successive, however, this accounting practice became legalized first in 2009 with the introduction of the BilMoG.

\section{Special regulation of current valuation for German banks}

With the introduction of the BilMoG in 2009, the German legislator intended to strengthen the information usefulness of financial accounting by partial approximation to the IFRS and an advanced use of the options of the EU fair value regulation. The application of the realization principle according to $\$ 252$ Abs. 1 no. 4 HGB was put up for discussion with regard to financial instruments. The realization principle is directly linked to the strict adherence of the acquisition cost principle as upper value limit pursuant to $\$ 253$ Para. 1 sent. 1 HGB and ought to prevent the disclosure of not realized profits in support of the creditor protection. Yet, the acquisition cost principle and the realization principle counteract a relocation of operating liability assets (company's sphere) to the non-liability area of the shareholder sphere, thus trying to compensate for the creditors to be more at risk. In contrast, the IFRS adapt more to extensive current value accounting (fair value), being more interested in the information function. In some respect quite similar to the basic idea of the organic accounting theory, the IFRS intends to achieve a "real" valuation rate for assets and a prompt disclosure of profits in line with the assumed information interest of the investors.

In order to strengthen the information function of the financial statement, the first draft of the BilMoG in 2007 provided for a compulsory valuation at current value for all financial instruments held for trading ( $\$ 253$ Para. 1 sent. 3 HGB-draft). In spite of a violation of the acquisition cost principle and disregard of the prohibition to disclose not realized profits; this was meant practical needs, since the current valuation of the mentioned financial instruments was common and to some extent already even described as a principle of orderly accounting before the BilMoG. This referred to the current valuation of commercial banks. At that time, apparently it was assumed that collecting of profits of financial instruments held for trading would represent a virtual securely realizable profit as a result of the business model in question. A re-adaption of the estimation concept in order to determine the current value would become dispensable under the largely inapplicable assumption, that active markets exist as a rule (in reality, the so called over-the counter (OTC) business is dominating the derivate business). Since market prices guarantee the foundation, an adequate reliability of the "realized" profits can be assumed. However, attention needs to be paid to the fact that initially no distribution ban for the (estimated) valuation variance between higher current value and acquisition cost according to the first draft of the BilMoG was stipulated. This would have meant that the not realized profits in question could have been considered for the distribution assessment in spite of the liability limitation.

Given the criticism towards the current value accounting, the second draft of the BilMoG suggested a certain compromise-solution, which obviously did not convince the federal council amongst others. The respective solution provided for the treatment of realizable but not yet realized profits for non-banks is being prohibited for distribution according to $\$ 268$ Para. HGB. The German Federal Council argued in a comment to limit the parity current value accounting users to financial industry according to $₫ 340 \mathrm{HGB}$ as a result of the continuing financial crisis and the eligible accusation of 
the fair value as accelerator. This again is rather incomprehensible since the current value ought to become compulsory for the crisis accelerating branch in particular. In contrast, for companies of the real economy no real need for current valuation could be discovered rightly. A corresponding limitation regarding the area of application would be justified as a result of the consideration of practical relevance, since it is assumed that the deviation of the current value involves higher efforts and severe assessment difficulties. The relevant suggestions of the federal council were implemented by the legislator in the final version of the BilMoG, in line with the opinion of the majority of experts in the legal committee, which was militating against the current valuation for all companies. Only the expert of the German Federal Bank argued in favor of a consequent distribution ban for unrealized profits, even though he did not want to argue further on accounting methods of banks due to a lack of special knowledge.

Financial instruments held for trading of companies in the credit and financial service sector demanded a deduction for risk on the current value according to $\$ 340$ e Para. 1 sent. 1 HGB as a result of the missing distribution ban in $\$ 268$ Para. 8 HGB. The deduction for risk should be calculated by means of financial methods (value at risk). But on the other hand, criticism was passed on a consequent distribution ban in the final legislative procedure. Thereupon the legislator decided on a yet another compromise solution: a lump-sum quota of $10 \%$ of the net income profits of the current business year has to be put aside as part of the fund for general bank crises until at least $50 \%$ of the average net income on financial instruments held for trading of the last five years are achieved ( $\$ 340 \mathrm{e}$ Para. 4 HGB). Whether a double safeguarding is achieved with the deduction of risk in connection with the special reserves endowment can be questioned. Still, the abandonment of a distribution ban is giving rise to the affecting of creditor protection.

In this context, the aforementioned barely-legal history of the valuation of assets of credit institutes at risk adapted current value is quite remarkable. Until the middle of the last decade, at least a portfolio assessment in terms of accumulated lower or cost of market principle was applied instead of an imparity separate valuation. The portfolio assessment allowed for an accumulation of not realized profits and losses on held for trading financial instruments as parity determined surplus of losses, disregarding the surplus of not realized profits. In spite of commercial realization principle and acquisition cost principle, the bank accounting in practice dared to adapt even more to the mark-to-market valuation, in parts already referred to as accounting principles. Hereby, it is giving rise to a distribution policy based on the IFRS-consolidated financial statement in favor of the shareholders and at the expense of the creditors' protection. Within the framework of the discussion on the BilMoG, the Central Credit Committee referred to this approach as common method, explicitly highlighting that not realized valuation profits already provided the basis for the assessment of profit distribution. Meanwhile, the invention of sector specific accounting principles has been criticized sharply. This derived from the proceedings of single commercial institutes conflicting with the law accordingly. On the other hand, as a result of the characteristics of the commercial transaction the violation of accounting principles is considered as appropriate. Even if branch specific accounting principles would exist, it can be questioned with regard to acquisition cost principle and realization principle why accounting principles should be of more relevance than the clearly defined legally codified regulations on accounting of acquisition costs.
Along the lines of commercial law, the tax law has been adapted as well: The fiscal acquisition cost principle according to $\$ 6$ Para. 1 EStG was violated with regard to certain aspects by the BilMoG in accordance with commercial law. Even though, the legislator intended to protect the tax neutrality of the accounting law reform. On the lines of the German Commercial Code and according to $₫ 6$ Abs. 1 no. $2 \mathrm{~b}$ EStG, respective credit and financial service providing institutes are requested to report on financial instruments held for trading at parity current value, less a deduction for risk according to $\$ 340$ e Para. 3 HGB, with regard to the determination of taxable income. However, the parallel commercial collection of special reserves for banking risks does not affect the fiscal determination. Hence, for the first time after the income tax law act of 1920 a taxation of not realized current value profits is affected. Thus, short term (virtual) fluctuations in the market price are directly taxable.

Although this proceeding was strictly forbidden in terms of tax law before the application of the BilMoG, in the course of a non-common law commercial bank accounting consciously accepted tax losses before the introduction of the BilMoG. This was verified by Naumann [17] stating in front of the legal committee of the German Parliament that this would be the reason why banks are today willing to accept the fair value method for taxation purposes, even though this is unfavorable in terms of taxation. In case something like a quasicontractual tax agreement between credit institutes and tax administration existed, within this context - also in case of a temporarily rising of the basis of assessment - the principle of legality of taxation could have been violated. Moreover, it is to be questioned whether voluntary tax payments were made by management in the interests of the shareholders. Even though, these payments could be interpreted as the price for the rising of potential distribution amount (at the expense of the creditor protection).

Now, a risk adapted current valuation is stipulated by the BilMoG in line with $₫ 340$ e HGB in $\$ 6$ para. 1 EStG. It is clarified that this method was illegal in terms of tax law before the BilMoG but that the banks are no longer expected to apply the acquisition cost principle. The fair value principle will be adapted - to a limited application area - by means of practical considerations for the determination of taxable income, or else the taxpayer would be forced to determine the acquisition costs of the financial instruments in the bookkeeping. The justification that the maintenance of the acquisition cost principle demands for a sample accounting is not convincing to the point.

\section{Critical Analysis of the (re-)introduction of the Parity Current Value Accounting into German Accounting Law}

\section{Impairment of the information purpose of the commercial balance sheet}

Apart from the creditor protection based on the determination of distributable profit, the commercial annual financial statement in addition has a secondary information function, which ought to be strengthened by the BilMoG by means of IFRS harmonization. For this purpose, the current value was presumed to be an appropriate measure. In case legitimate doubts are neglected that with regard to commercial banks both the (IFRS) consolidated financial statement and the individual financial statement are in focus of the addressee for information purposes and the distribution determination function of 
the single financial statement is overlooked, it is imperative to doubt the information purpose of the measure in question.

Being an attribute of the IFRS accounting, the current value is primarily responsible for providing decision useful information to (potential) investors with regard to buying, holding and selling of shares of the company in question. If the value of the share exceeds the share price, it is recommended to buy shares, otherwise to sell. In case of a given market price, the information on the value of the share, e.g. value of the company is decision useful.

It may be attempted to determine this (total) value by single valuation of assets and debts. However, this is impossible without taking into account the self-generated goodwill, thus corresponding to the intention of a fair value accounting method, similar to the organic present value financial statement. Apart from the accompanying imponderability, this monistic understanding of the information function cannot be applied to the commercial financial statement aimed at the reconciliation of interests. Besides, so far an adjusted comparably profit was taken as a standard for (commercial) information or accountability function.

In case of a volatile market oriented valuation the profit is influenced by random fluctuations, not accounting for the aim of this profit oriented measuring method. At best, current valuation can sub serve for a capital oriented information concept. However, the commercial balance sheet cannot ensure this concept due to the respective re-objectification.

Taken together, the information usefulness of current valuation in the commercial law is to be questioned. Yet, in addition advanced reliability and incentive problems exist as a result of missing market prices. The short-term oriented management could argue that the economic circumstances developed unfavorably, after demonstrating own efforts more positively based on estimations. Corresponding compensation could have been paid out already and, similar to distributions, is not retrievable. Investing banks are interested in the information function of the IFRS consolidated financial statement. Therefore, in terms of commercial law, the influence on the distribution assessment should govern and should not be an expected improvement of the information purpose. Hence, this puts the legal political aim of commercial current valuation into question. Moreover, in order to fulfill the information purpose, reporting of the current value in the notes seems to be less critical and thus more convincing.

\section{Impairment of the commercial balance sheet purpose to protect creditors}

Credit institutes upgrade the information purpose by implementation of a parity fair value valuation of financial instruments held for trading. Due to the option to distribute not realized valuation profits at the expense of the primary accounting purpose, the protection of the creditors by a distribution limit, this appreciation calls for criticism. Yet, the legislator did not comply with the demand for a complete distribution ban regarding this special regulation for banks. Instead, - as already mentioned - a deduction for risk and the building up of special reserves were stipulated. The valueat-risk deduction for risk ought to allow for the probability of default for not realized profits, yet, it is a finance theoretical concept that does not aim at the assessment of not realized profits. Thus, it does not account for a surrogate according to $\$ 268$ Para. 8 HGB for the planned distribution ban. However, the legislator accepts a disproportionate higher risk for the creditors as opposed to a consequent distribution ban. From an accounting law and economic perspective, a financial controversial discussed deduction for risk is not satisfying. Even a combination of deduction for risk and the building up of special reserves cannot keep up with an equal creditor's protection as in case of the distribution ban for unrealized profits. Furthermore, the anti-cyclical effect is addressed here. Again, a consequent distribution ban would be preferred in terms of commercial law. Unfortunately, the accounting law reform of 2009 (BilMoG) did not comply with the basic considerations of the stock law act of 1884, not allowing for the distribution of not realized and not retrievable current value profits. Now, they may be distributed again.

\section{Impairment of the purposes and principles of the tax balance sheet}

The determination of taxable income has to comply with certain economic and constitutionally criteria. In addition the German legislator aimed for a neutrality of taxation of the balance sheet reform by the BilMoG. This requirement can be interpreted as pare to criteria. According to the modifications of the law reform of 2009, neither the taxpayer nor the tax authorities may be treated inferior. In practice, the intended neutrality of taxation could mean that the new regulations do not allow for a modification of the assessment basis. Yet, as a result of the partial violation of the realization principle this requirement cannot be fulfilled. This holds true, even if the neutrality of taxation would mean that preferably decisions should not be influenced (decision neutrality of the balance sheet reform). In actuality, it is a form of fire sale as a result of the taxation of not realized profits, if the taxpayer needs to sell a financial instrument earlier as planned, e.g. before an expected further price increase in order to comply with the tax burden of not realized profits. Thus, an impairment of the allocation efficiency can be observed. Potential financial losses result from a lack of liquidity, being a basic requirement for the fiscal capacity. As a result, because of the violation of the realization principle within the framework of the current valuation the profit-related tax becomes a real property tax.

Yet, the compatibility with the ability-to-pay-principle it is to be doubted. However, this principle is to be regarded as the more dominant criteria for tax equity. The principle of taxation uniformity is violated, if equal situations, showing the same capacity, are taxed differently. Now, this is true for commercial transactions of banks (fair value accounting) and non-banks (acquisition cost accounting). Yet, there is no guarantee that higher economic performance leads to higher taxation because of the differences regarding the determination of not realized profits in the assessment basis. Without having to define the term economic performance in detail, the inexpediency of the special regulation for credit institutions is proven, since the attributes realized and realizable cannot be equalized with regard to the profit determination and taxation. In fact, the income assessment can be effected as realized capital growth, according to its intended economic theoretical purpose and measure of fiscal capacity. This assessment aims at a nominal maintenance of capital and corresponds to the accounting principles, especially the realization principle. Arguments in favor of a current (fair) value oriented collection of not realized profits can be found only in case the determination standard for the fiscal capacity turns away from this basic concept, following the lines of an unrealistic neoclassical modeling.

Also the German legislator recognized the fundamental problem of the BilMoG: it is to be verified whether this annual financial statement 
still can comply with its previous function, as a result of the authoritative principle to present the fiscal capacity of the balancing trader. The information function of the commercial balance sheet comes to the fore and the realization principle as a measure of fiscal capacity is modified partially. Hence, it needs to be analyzed whether an independent determination of taxable income is necessary in order to preserve a taxation based on the individual capacity. Since the highly problematic information oriented current valuation according to the BilMoG has been codified in the tax law explicitly, it is to be questioned for what reason. Due to the upgrade of the information function an independent tax law is requested, if the corresponding tax reservation -to adapt only to the regulations in line with the accounting principles- is cancelled by the direct adoption and codification of the current valuation in $₫ 6$ Para. 1 no. $2 \mathrm{~b}$ EStG.

\section{Conclusion}

From a historic perspective, the commercial valuation of assets to current value, violating of the acquisition cost principle (parity current valuation or lower of cost or market principle) is of great importance in Germany until the stock law act of 1884 . Since that time until the introduction of the German Accounting Law Modernisation Act (BilMoG) of 2009, an exceeding of the (continuing) acquisition costs with regard to the disclosure of the higher current value in the commercial balance sheet was not allowed. Initially this was true only for certain legal forms but became compulsory for all traders in question at a later date. This proceeding provided for the realization principle, which in turn was regarded as a major part of the balance sheet based maintenance of capital and the creditor protection. With the introduction of the principle of correlation and the accruals basis accounting, also the question was raised concerning the "appropriate" tax valuation for acquired goods in terms of fiscal law. The article 185a ADHGB of the stock law act of 1884 stipulated the acquisition costs as upper value limit for private limited partnership on shares and stock corporations, yet this requirement was followed for the first time within the income tax act of 1934 not allowing to be exceeded since that time.

The present paper substantially enhances the literature by including an additional tax related evaluation as well as a critical analysis of the fair value measurement after the accounting law reform act in 2009 against the background of the latest financial crisis. It was only with the German accounting law reform as a result of the BilMoG that credit and financial service institutions were allowed to valuate financial instruments held for trading at a (higher) current value, thus violating the acquisition cost and realization principle. This special regulation with regard to commercial and tax law was stipulated in $\S$ 340e Para. 3, 4 HGB and $\$ 6$ Para. 1 no. $2 \mathrm{~b}$ EStG. The new regulation was at the expense of the creditor protection because the not realized valuation profit was added to the distribution amount and a legal distribution ban in line with $₫ 268$ Para. 8 HGB was missing. Against the background of the impairment of the creditor protection as well as the fiscal ability-to-pay-principle and the taxation equity, the amendment in favor of the current valuation is to be rejected from a commercial and fiscal perspective. In fact, the realization principle should have been preserved in the IFRS forcefully as a result of the negative experiences during the financial crisis in 2008-09 and the strengthened influence of the "fair value".

The former legislator realized the negative effects of the parity current valuation on the founder crisis at that time in the German Empire within the stock law act of 1884 . Hence, he was criticizing a conscienceless over-evaluation of the assets under the umbrella of commercial usance. The German legislator did not draw a similar conclusion within the BilMoG regarding the assets held for trading of credit institutions, though he perhaps should have. Yet, it is to be questioned why the present German legislator decided on a compromise solution in spite of comparable counter-arguments. The compromise allows for the introduction of current value accounting only in the crisis-relevant bank sector.

\section{References}

1. Velte P, Haaker A (2012) Entwicklung der Zeitwertbilanzierung im Handels- und Steuerrecht. Steuer und Wirtschaft 88: 56-70.

2. Haaker A, Velte P (2013) Zur Geschichte der Zeitwertbilanzierung in Deutschland. Zeitschrift für Unternehmensgeschichte 58: 73-104.

3. Richard J (2004) The Secret Past of Fair Value: Lessons from History Applied to the French Case. Accounting in Europe 1: 95-107.

4. Kadel J (2005) Außerplanmaessige Abschreibung und Zeitwert in der deutschen und US-amerikanischen Handels- und Steuerbilanz. Hamburg: Dr. Kovac.

5. Keyszner H (1875) Aktienzinsen, Dividende und Bilanz. Archiv fuer Theorie und Praxis fuer das allgemeine Handelsrecht 32: 99-145.

6. Loewenfeld B (1879) Das Recht der Actien-Gesellschaften. Berlin: Guttentag.

7. Simon H (1899) Die Bilanzen der Aktiengesellschaften und der Kommanditgesellschaften auf Aktien. 3rd ed. Berlin: Guttentag.

8. Schmidt F (1929) Die organische Tageswertbilanz. 3rd ed. Leipzig: Gloeckner.

9. Fischer R (1909) Ueber die Grundlagen der Bilanzwerte. Leipzig: Veit \& Comp.

10. Schmalenbach E (1919) Grundlagen dynamischer Bilanzlehre. Zeitschrift fuer handelswirtschaftliche Forschung 13: 1-150.

11. Preußisches Oberverwaltungsgericht (1895) Rep. V.5/95 13.12.1895. Entscheidungen des Koeniglich Preußischen Oberverwaltungsgerichts in Staatssteuersachen. Ergaenzungsband IV: 241-242.

12. Reichsgericht (1905) 4331/04 2.3.1905. RGSt:1.

13. Saechsisches Oberverwaltungsgericht (1901) Saechsische Jahrbuecher 1: 343-344.

14. Preußisches Oberverwaltungsgericht (1896) Rep. V.6/86 20.4.1896. OVGE:63.

15. Preußisches Ober-Tribunal (1872) 4.11.1872. Entscheidungen des Koeniglichen Ober-Tribunals 68:132.

16. Mirre L (1913) Gemeiner Wert und Ertragswert. Zeitschrift des Deutschen Notarvereins 12:155-176.

17. Deutsche Bundesbank (2008) Stellungnahme zur Anhoerung des Rechtsausschusses am 17.12.2008 zum Entwurf eines Bilanzrechtsmodernisierungsgesetzes. Frankfurt am Main. 